\title{
Form of Urban Tourism based on Khon Kaen Identity
}

\author{
Chaithawat Siribowonphitak ${ }^{1}$, Jinnapas Pathumporn, Ph.D. ${ }^{2}$ and Ranee Esichaikul, Ph.D. ${ }^{3}$ \\ ${ }^{1}$ Ph.D. Student, Faculty of Business Administration and Accountancy, \\ Khon Kaen University, Thailand E-mail: Siribowonphitak@gmail.com \\ ${ }^{2}$ Lecturer in Tourism Management, Faculty of Business Administration and Accountancy, \\ Khon Kaen University, Thailand E-mail: Jinnapas_p@hotmail.com \\ ${ }^{3}$ Associate Professor in Faculty of Management, Sukhothai Thammathirat Open University, Thailand \\ E-mail: esicha@gmail.com
}

\begin{abstract}
The purpose of this article is to study the form of urban tourism based on Khon Kaen identity, Thailand. According to the study, Khon Kaen is famous for its woven fabrics, especially in local districts and especially Mudmee silk and cotton. Dyed fabrics are available in shops at the famous walking streets such as Silk Road or available in front of local houses. In addition, there is Phuvieng Dinosaur Museum, which is a geological museum where dinosaur fossils are displayed with modern facilities and is highly popularized. There are also local traditions and concepts which should be promoted and developed for tourism which include 1) the fact that Khon Kaen is an activity and festival city, 2) the fact that Khon Kaen is a city of two eras which are the modern era and the ancient era, and 3) the fact that there is a variety of local and famous wisdoms in Khon Kaen.
\end{abstract}

Keywords: Urban Tourism, Khon Kaen, Identity

\section{Background and Significance of Problem}

United Nations World Tourism (UNWTO) predicts that in 2020 there will be approximately 1,600 million international tourists, and the tendency of the popular tourist attractions is East Asia Pacific and South East Asia (United Nations World Tourism, 2015). In addition, the increasing change of economic mechanisms, aging society and urbanization bring prosperity and business opportunities. Governments, therefore, place importance on enhancing the competitive ability to seize the share of global market, especially countries in Asia which implement identity promotion strategies for their cities in order to attract more tourists. The missions of the tourism sector have been integrated with all dimensions of the national development (Tourism Authority of Thailand, 2016).

Thailand considers tourism as the national agenda. Apart from Bangkok, Phuket, Chonuri, Surat Thani and Chiang Mai which are the main tourism cities which support urban tourism, it is apparent that there is no province in the northeast which is ranked the top tourist destination. There are many cities that have a unique identity such as Barium which is a speed city and Chiang Khan which is a cultural city along Mekong River achieving its tourism success in a high scale (Thailand Creative \& Design, 2016). However, there are many cities with potential and opportunities to develop themselves into tourism cities, especially Khon Kaen Province where the number of tourists has increased after World Tourism Day Event was held in 2016 measured by the number of flights and regional route expansion. Khon Kaen has also been appointed as the significant city of the northeast, and it has a continuous foundation development. Consequently, a 4-year development framework (2015-2018) has been determined. There are several projects being initiated tofacilitate the tourism and convenient access to the area. It can be seen through the investment of the private conference and product exhibition hall which will open at the end of 2018 and Khan Kaen Airport which is being improved to the international scale (Yuttasak Supasorn, 2016). 
Even though Khon Kaen is ready for urbanization in many aspects, various tourism strategies and product development strategies have not been successful. The tourism products are not attractive enough to make tourist recognize Khon Kaen well; it lacks balance development of demand and supply. If the administrators can use the strategies and understand the tourists' behavior and this new type of tourism, tourism opportunities will ensue (Nantakwang Sirasuntorn, 2016). Urbanization can act as a magnet attracting tourists and disperse them to certain areas according to their needs. In addition, tourism concept should be based on the identity which is really attractive in order to present the unique characteristic of the province by considering tourists' behaviors integrated with the identity of existing tourism resources (Wichai Srikwan, 2015). As for tourism development and promotion, the large number of tourists is not always important to develop the destination, and the administrators should focus on the strengths and unique characteristics. Despite certain cities with limited tourism resources, if they are developed and promoted well, they can achieve the tourism success (Mingsan Kawsa-ad, 2015). Strategy planning must include both public and private sectors and powerful structures which can be used to operate the tourism directly and indirectly with the focus on development of all dimensions (Narisa Kamkaen, 2014). Therefore, this article aims to study the form of urban tourism based on the identity of Khon Kaen Province. The objectives are to study both demand and supply based on the existing tourism resources and to identify the identity that leads to strategies appropriate for urban tourism in Khon Kaen which can be integrated and in accordance with the implementation of local, regional and national strategic plans.

\section{Literature Review}

In this article, the researcher has studied the concepts, theories and relevant documents and research papers in order to provide the overview, analyze and synthesize data to support the results. The literature consists of definitions of urban tourism (Wall G. \& Mathieson A., 2011, Woodside A., Cruickshank B., \& Dehuang N., 2009, Napira Travel, 2013). The components of urban tourism which differentiate it from other types of tourism are lack of season and that it relies on existing tourism resources which can be recycled to create new tourism activities and tourism products (Beedie P., 2010, Ashworth G. \& Page S. J., 2011, Douglas N. \& Derrett R., 2010,Gospodini A., 2009). Urban tourism can be classified by characteristics of the society, culture and environment of that city. There are consistent direct and indirect supporting factors for urban tourism that affect the promotion of urban tourists (Law, 2002) which are 1) historic city, 2) cultural city (i.e. cultural industry), 3) business city, 4) sport city, 5) nightlife city, 6) leisure shopping city and 7) tourist city (Burtenshaw et al., 1991, Law C.M., 1997).

\section{Urban Tourism}

Urban tourism is tourism that is related to local lifestyles, cultures. It refers to a city which is part of cultural tourism, lifestyles, society and community and leisure or sport activities (Mahasarakham University, 2013). It also refers to participation in urban festivals, meeting and dinning, shopping, nightlife (Verbeke, J., 1999), sightseeing the city landscape and architecture, including using services in the urban area. In addition, it refers to tourist spots such as entertainments, arts, department stores, theaters and activities. It may be the destination or the gateway to other cities for business purposes, seminar conferences and festivals (Bill Bramwell, 1999).

\section{Urban Tourism in Khon Kaen, Thailand}

According to the study on tourism state in Khon Kaen, it reveals that at the present time, Khon Kaen is firstly important to economy and tourism of the northeast and considered the hub of the central northeast and the southern north. Also, many agencies perceive the potentiality of tourism. Khon Kaen is the hub of commerce and education in the northeast of Thailand and considered the popular destination where tourists visit to know cultures and traditions. Khon Kaen is also well known as the source of Mudmee Silk production and as the center city of "the Development Plan of Economic Area" and links Thailand, Myanmar and Vietnam together. Furthermore, Khon Kaen is the hub of commerce and transportation and as the gate through Indochina and the 
south of China. The aforesaid factors make Khon Kaen developed as one of the important cities of Thailand. Also, Khon Kaen is the hub of commerce and education in the northeast of Thailand and considered the popular destination where tourists visit to know cultures and traditions (Federation of Thai Tourist Industries, 2017, Office of Conference and Exhibition Promotion, 2017).

Khon Kaen includes many important tourist attractions that are the 100-year ancient monument, the place of civilization since prehistory's and the national park. It makes tourism as the main activity. However, the tourist resource of Khon Kaen is not completely and successfully developed after the policy had planned for many years because of the policy that has changed in different city administrators (Khon Kaen Municipality, 2017). According to the information of 20-hotel extension provided by the Office of Tourism of Thailand in Khon Kaen, most of them are the small and medium hotels that indicate the increase of tourists at moderate level including the increase of aviation industry that there are more than 23 flights in Khon Kaen Airport with the wider parking lot and more terminals. According to the statistics, at the present time, there are 3.8 million tourists per year who lodge for a night and roam around increased more than 20 percent from the previous year. Most of them are Thai tourists and the northeastern region where is usually visited (Khon Kaen Municipality, 2017, Northeastern Office of Tourism of Thailand Section 3, 2017) as the following table:

Table 1: Statistics of Khon Kaen Tourists

\begin{tabular}{|l|c|c|c|}
\hline \multicolumn{1}{|c|}{ Kind of Data } & Year 2014 & Year 2015 & Year 2016 \\
\hline Thai Tourist & $3,531,828$ & $3,609,152$ & $3,818,917$ \\
\hline Visitor and Foreigner & 61,214 & 60,732 & 62,729 \\
\hline Total & $\mathbf{3 , 5 9 3 , 0 4 2}$ & $\mathbf{3 , 6 6 9 , 8 8 4}$ & $\mathbf{3 , 8 8 1 , 6 4 6}$ \\
\hline
\end{tabular}

Source: Department of Tourism, Ministry of Tourism and Sports (2017)

\section{Form of Urban Tourism based on Khon Kaen Identity}

According to the study on local identity, culture and/or wisdom, it has been found that Khon Kaen is famous for its woven fabrics, especially in local districts and especially Mudmee silk and cotton. Dyed fabrics are available in shops at the famous walking streets such as Silk Road or available in front of local houses.In addition, there is Phuvieng Dinosaur Museum, which is a geological museum where dinosaur fossils are displayed with modern facilities and is highly popularized. The tourist attractions in Khon Kaen with the potential to facilitate tourists are as follows.

Table 2: Potential Tourist Attraction of Khon Kaen

\begin{tabular}{|c|c|c|}
\hline \multicolumn{3}{|c|}{ Type of Tourist Attraction } \\
\hline Nature & History/Art and Culture & Activity \\
\hline 1. Kaen Nakhon Lake & 1. Shrine of the City-God & 1.Dok Khun Siang Khaen Festival and \\
\hline 2. $72^{\text {nd }}$ Anniversary Queen Sirikit & 2.National Museum of Khon Kaen & Khao Niao Road \\
\hline Park & 3. Hong Moon Mueang Khon Kaen City & 2. Phuk Siao Tradition and Red Cross Fair \\
\hline 3. Uronrat Dam & Museum & 3. King Cobra Village \\
\hline 4. Bang Saen 2 and Jomtien & 4. The Great Buddha's Relic of Kaen & 4. Worship Festival of Kham Kaen \\
\hline Beach & Nakhon $\left(9^{\text {th }}\right.$ Floor Buddha's Relic) & Buddha's Relic \\
\hline 5. Phu Kao-Phu Pankam National & 5. Golden Jubilee Convention Hall of & 5.Scientific Center for Education of Khon \\
\hline Park & Khon Kaen & Kaen \\
\hline 6. Nam Pong National Park & 6. Isan Art and Culture Center (Saeng & \\
\hline 7. Phu Vieng National Park & Arun Temple) & \\
\hline 8. Heaven Beach & 7. Chaiya Sri Temple and Sin Sai Mural & \\
\hline 9. Pattaya 2 & 8. Huen Lao & \\
\hline 10. Phu Pha Man National Park & 9. Kham Kaen Buddha's Relic & \\
\hline
\end{tabular}




\begin{tabular}{|l|l|l|}
\hline \multicolumn{2}{|c|}{ Type of Tourist Attraction } \\
\hline Nature & \multicolumn{1}{|c|}{ History/Art and Culture } & Activity \\
\hline 11. Tham Pu Lup & 10. Ku Prapha Chai & \\
12. Pha Nok Khao & 11. Phu Vieng Dinosaur Museum & \\
& 12.Village of Thai Buffalo Conservation & \\
& 13. Non Mueang Ancient City & \\
& 14. Buddhist Temple of Sra Thong Baan & \\
& Bua Temple & \\
& 15. Udom Kongka Kiri Khet Temple & \\
& 16.Building of 6 ${ }^{\text {th }}$ Anniversary Queen & \\
& Sirikit Chalermprakiet & \\
& 17. Pueai Noi Castle & \\
& 18. Sra Bua Kaew Temple & \\
\multicolumn{3}{|c|}{ Source: Office of Tourism and Sports of Khon Kaen (2017) } \\
\hline
\end{tabular}

According to Khon Kaen Office of Culture and Tourism of Thailand, Khon Kaen Office and Khon Kaen Municipality as the agencies that provide the main information, it reveals that Isan language is the identity of Isan people and Khon Kaen, and the promotion of Isan language will lead to pride on their identity. It is considered maintaining Isan language, lifestyles, thoughts and spirit of local people; moreover, it is compatible with the objectives of international contracts such as the Convention of Children Rights by United Nations Organization. Khon Kaen Municipality has an idea to draft the course of Isan language and taught by Tai Noi language in order to promote local people to realize values and pride on their own local cultures. Many local agencies must be promoted to participate in decision of local business much more because in the future, the local politician's policy tends to be changed in order to match the need of better recovering Isan cultures. Currently, using Isan language in community is hardly found and getting faded away because parents have their children use the interlanguage when talking or having conversation. Using Isan language will remain only in the rural area that is getting faded away as well from other existent languages. Therefore, Isan language should be conserved so that a new generation can learn it. According to the point of identity, culture and/or local wisdom of Khon Kaen, the local arts and cultures that should be promoted and developed for tourism are apparently as follows:

- Khon Kaen is the city of activities and festivals; that is to say, the Songkran Festival, the Dok Khun Siang Khaen Festival and Khao Niao Road, the Ok Phansa Kindle Lamp Festival, the International Silk Festival, Phuk Siao Tradition and RedCross Fair, the Si Than Festival, the Boon Som Ma Bucha Nam, the Tour de Pong Neep Bike Race or "Ride for Sound of Lute", the Visit of Isan Organer, the Tak Bat Thewo Alms Giving Fair, the Loi Pratip Bucha Ok Phansa Festival, the International Plant Festival, the Countdown Festival of Khon Kaen including the activity of recovering Sin Sai literature, and there are more than 19 bands of folksinger in Khon Kaen that will push and promote the identity of Khon Kaen in performances, activities and festivals based on the local cultures as well.

- Khon Kaen is considered the two-era city; that is to say, the contemporary city that is growing and modern transportation, the hub of business and the ancient one that is the Old City of Khon Kaen,the Buddha's Relic of Kaen Nakhon, the Pueai Noi Castle that is far from the city and considered the Hindu shrine around 16th-17th Buddhist century, the Baphuon-Angkor Wat arts in the age of Khmer cultures and the stone inscription around 17th Buddhist century.

- The well-known local wisdom of Khon Kaen is Mudmee Silk with the procedures from selecting silk, designing Mudmee patterns and dyeing that is the delicate procedure. The prominent points of Mudmee Silk are beauty and distinctive patterns. The identities of Mudmee Silk are the pattern and the weaving technique. The inherited ancient pattern is considered the prototype and ancient pattern of Khon Kaen Silk that includes Meekong pattern, Khan Mak Beng pattern and Khor Phra Thep pattern or candlestick pattern. Most of them are the 3-heddle weaving that makes the texture tight and smooth with the color and pattern of fabric that is opaquer than the other side. The unique colors are violet, red, green and chestnut. Another unique weaving of rural people is Poom Fabric ir Nha Nang Fabric with the characteristics of loincloth 
including Mudmee pattern aroundthe bottom of fabric, Mudmee Nha Nang pattern and Mudmee pattern around both sides of fabric edge.

\section{Conclusion}

It can be concluded, in this article, that tourism has been considered as the national agenda of Thailand. According to urbanization, it results in growth-led tourism with increasing tendency of urbanization and urban activities. This can be observed from the continuously increasing number of tourists. The tourists will be clustered in the urban areas. Most of the tourists are MICE groups, business groups, public agency groups, private company groups, those who travel by private car, those who travel for recreation and those who travel to transit to other nearby provinces who use Khon Kaen as the gateway.

According to such characteristics, Khon Kaen Province falls into urban tourism category for several reasons. 1) Mostly, Khon Kaen has the tourism resources and products created by men to fulfill the tourists' needs. There are new activities and modification of places to make the province relevant (Terdchai Chuaybamroon, 2009). 2) The urban zone has changed its travel landscape as a result of sudden economic growth. Over the past 3 years, there have been MICE industry and service development, promotion of business investment, expansion of industrial zone, evolution to smart city, more architectural and landscape sightseeing activities and available amenities in the urban areas. The attractions include entertainment, arts, department stores, theaters and activities. As a result of urbanization, there is a combination of old city and modern city in Khon Kaen. Nowadays, traditional cultures are being preserved; however, it is due to consequences of social and economic development and change, exchange of knowledge and foreign cultures, and advance development.

Therefore, it can be summarized that the type of urban tourism based on the identity of Khon Kaenis considered the city of conference, seminar and festival or event based on the identity from holding activities and festivals all year; moreover, Khon Kaen is considered the two-era city that means the contemporary city that is growing and the ancient one with several and well-known local wisdoms.

\section{References}

[1] Ashworth G. \& Page S. J. (2011). Urban tourism research: Recent progress and current paradoxes. Tourism Management, 1-15.

[2] Ashworth, G. J. (1989). Urban tourism: an imbalance in attention. In C. Cooper (Ed.),Progress in tourism, recreation and hospitality management, Vol. 1 (pp. 33-54).London: Belhaven

[3] Beedie P. (2010). The adventure of urban tourism. Journal of Travel \& Tourism , 37-48.

[4] Bill Bramwell. (1999). User satisfaction and product development in urban tourism. Sheffield Hallam: Tourism Management.

[5] Department of Tourism. (2016). Statistics of foreign tourists entering Thailand in 2015. Bangkok: Department of Tourism. Ministry of Tourism and Sports.

[6] Douglas N. \& Derrett R. (2010). Special interest tourism. John Wiley and Sons Australia: Sons.

[7] Edwards, D., Griffin, T., Hayllar, B., (2008). Urban tourism research. Developing an Agenda, Annals of Tourism Research, Vol. 35, No. 4, p. 1032-1052.

[8] Gospodini A. (2009). Urban design, urban space morphology, urban tourism: an emerging new paradigm concerning their relationship. European Planning Studies, 925-934.

[9] Hall, C. M., \& Page, S. J. (2009). Progress in tourism management: from the geography of tourism to geographies of tourism: a review. Tourism Management,30(1), 3-16. 
[10] Howie, Frank. (2003). Managing Tourist Destination, EMEA: Thomson Learning.

[11] Khon Kaen Municipality. (2016). Policy of Khon Kaen Municipality, 2016-2021. Khon Kaen Municipality Office Khon Kaen.

[12] Khon Kaen Provincial Office. (2016). Development Strategy for Khon Kaen 4 years (2014-2018) Office of Khon Kaen, Khon Kaen Development Strategy Group.

[13] Law C. (1993). Urban Tourism Attracting Visitors to large Cities. London : Mansell.

[14] Law, C. (2002). Urban Tourism: The visitor economy and the growth of large Cities, EMEA: Thomson Learning.

[15] Law, C. M. (Ed.). (1993). urban tourism: Attracting visitors to large cities. London: Mansell.

[16] Law, C. M. (Ed.). (1996). Tourism in major cities. London: Thomson International London: Continuum.

[17] Maha Sarakham University. (2013). Different types of tourism. Mahasarakrm university. Mahasarakham province.

[18] Minciu, Rodica, (2005), Economia turismului, București: Editura Uranus.

[19] Mingsan Kawsa-ad. (2015). Urban Development in the Age of Lifestyle Tourism Bangkok: Thailand Research Fund (TRF).

[20] Ministry of Tourism and Sports. (2016). The Human Resources Development for Tourism Administration Project, Bangkok: Ministry of Tourism and Sports.

[21] Ministry of Tourism and Sports. (2016).Thailand Tourism Strategy 2015 - 2020. 2015: Ministry of Tourism and Sports Thailand.

[22] Nantakwang Sirasuntorn. (2016). New Urban Travelscape: Tourism Landscape Talk Tourism Trend Talk II.Bangkok: Thailand Tourism Education Center (TAT).22-27

[23] Napira T. (2013). Travel vocabulary Bangkok: Napira Travel Stylist Company.

[24] Narisa Kamkaen. (2014). Synthesis of research, tourism and future research directions. Bangkok: Thailand Research Fund (TRF).

[25] Terdchai Chuaybamroong. (2009). Wisdom for creative local development. King Prajadhipok Institute.Thailand Creative \& Design. (2016). Policy on Urban Planning. Bangkok.TCDCCONNECT.

[26] Tourism Authority of Thailand. (2016). Tourism Trend Talk,. Tourism Trend Talk. Bangkok: Tourism Authority of Thailand.33-44.

[27] United Nations World Tourism. (2015). Tourism highlights. Madrid: United Nations World Tourism Organization.

[28] Verbeke, J. (1999). Scanning musuem visitors: urban tourism marketing. Annals of Tourism Research , 364-375.

[29] Wall G. \& Mathieson A. (2011). Tourism: Change, impacts and opportunities. Pearson, 47-58.

[30] Wichai Srikwan. (2015). Brand-new travel season, set a long slogan. Bangkok: GM Online.

[31] Woodside A., Cruickshank B., \& Dehuang N. (2009). Stories visitors tell about Italian cities as destination icons. Tourism Management, 162-174.

[32] World Economic Forum. (2015). The Global Competitiveness Report 2015-2016. World Economic Forum USA.

[33] Yuttasak Supasorn. (2016). TAT Promotion Khon Kaen Model 5 million people in northeasternThailand. Bangkok: Economic base. 